\title{
A Prospective Cohort Study on IRS Gene Polymorphisms in Type 2 Diabetes Mellitus Patients during Severe/Acute Hyperglycemia Phase 1: Association with Insulin Resistance
}

\author{
Hasniza Zaman Huri ${ }^{1,2 *}$, Mohd Makmor-Bakry ${ }^{3}$, Rosnani Hashim ${ }^{4}$, Norlaila \\ Mustafa ${ }^{5}$ and Wan Zurinah Wan Ngah $^{6}$ \\ ${ }^{1}$ Department of Pharmacy, Faculty of Medicine, University of Malaya, 50603 Kuala Lumpur, Malaysia, ${ }^{2}$ Clinical Investigation \\ Centre, 13th Floor, Main Tower University of Malaya Medical Centre, 59100 Lembah Pantai, Kuala Lumpur, Malaysia, ${ }^{3}$ Faculty \\ of Pharmacy, Universiti Kebangsaan Malaysia, Kuala Lumpur, Malaysia, ${ }^{4}$ Faculty of Pharmacy, Cyberjaya University College of \\ Medical Sciences Cyberjaya, Malaysia, ${ }^{5}$ Department of Medicine, Faculty of Medicine, Universiti Kebangsaan Malaysia, Kuala \\ Lumpur, Malaysia, ${ }^{6}$ Department of Biochemistry, Faculty of Medicine, Universiti Kebangsaan Malaysia, Kuala Lumpur, \\ Malaysia
}

*For correspondence: Email: hasnizazh@um.edu.my, hasnizazh@ummc.edu.my; Tel: +603 79676659

\begin{abstract}
Purpose: To investigate the genetic polymorphisms that may contribute to the worsening of insulin resistance in type 2 diabetes mellitus (T2DM) with severe or acute hyperglycemia.

Methods: This is a prospective cohort study involving 156 T2DM patients with severe or acute hyperglycemia from all medical wards of the National University of Malaysia Medical Centre (UKMMC) that were placed on insulin therapy. The polymerase chain reaction-restriction fragment length polymorphism (PCR-RFLP) method was used to determine the genetic association of insulin receptor substrate (IRS) gene with insulin resistance. Insulin resistance status was determined using the homeostatic model assessment for insulin resistance (HOMA-IR) index.

Results: IRS1 polymorphisms were associated with increased insulin resistance $\left(X^{2}=5.09, p=0.023\right)$ in T2DM patients with severe/acute hyperglycemia. IRS2 polymorphisms were not associated with insulin resistance $\left(X^{2}=0.69, p=0.406\right)$ in this group of patients.

Conclusion: IRS1 genetic factor alone may be a significant genetic determinant for insulin resistance in T2DM patients during severe/acute phase hyperglycemia.
\end{abstract}

Keywords: Insulin receptor substrate, Genetic, Polymorphism, Diabetes, Insulin resistance, Hyperglycemia, IRS1, IRS2

Tropical Journal of Pharmaceutical Research is indexed by Science Citation Index (SciSearch), Scopus, International Pharmaceutical Abstract, Chemical Abstracts, Embase, Index Copernicus, EBSCO, African Index Medicus, JournalSeek, Journal Citation Reports/Science Edition, Directory of Open Access Journals (DOAJ), African Journal Online, Bioline International, Open-J-Gate and Pharmacy Abstracts

\section{INTRODUCTION}

Patients with type 2 diabetes mellitus (T2DM) are frequently admitted to the hospital because of severe or acute hyperglycemic attacks that are secondary to acute infections, acute myocardial infarctions, acute stroke and non-compliance to medications [1]. Despite a variety of theories describing the complexity of managing patients with severe/acute hyperglycemia, none of the previous studies looked extensively at the possibility that genetic polymorphisms could be a factor influencing insulin resistance. Insulin is the key hormone for glucose and lipid metabolism. Substrate molecules for the insulin receptor or insulin receptor substrates (IRS) are important 
intermediates in insulin signaling and play key roles in maintaining the basic functions of cell growth, survival, and metabolism [2]. Of four genes in the IRS system (IRS1, IRS2, IRS3, and IRS4), only IRS1 and IRS2 play an important role in glucose metabolism [2].

Defects in post-receptor insulin signaling are the main reasons for insulin resistance in target tissues that affect glycemic control [3]. Specifically, this defect was featured in the inhibition of specific signaling pathways of PI3K/Akt that are associated with positive insulin actions on glucose and lipid metabolism [4]. Polymorphisms in the IRS gene family associated with insulin resistance [4]. The Gly972Arg polymorphism in the insulin receptor substrate-1 (IRS1) gene reduces tyrosine phosphorylation by more than $60 \%$ and also acts as a competitive inhibitor for insulin receptor (IR) and insulin-like growth factor receptor-1 (IGF-1R) autophosphorylation [4]. Nevertheless, the impact of IRS gene polymorphisms on insulin resistance in T2DM patients with severe/acute hyperglycemia has not been explored.

Therefore, identifying genetic predictors for increased insulin resistance would complement other predictors to optimize the management and treatment of T2DM during severe/acute phase hyperglycemia.

\section{EXPERIMENTAL}

\section{Materials and chemical reagents}

Wizard $®$ Genomic DNA Purification Kit, PCR Master Mix, and 6x blue/orange loading dye were supplied by Promega (Madison, WI, USA). Water (molecular biology grade) was from SigmaAldrich (Irvine, UK). Ethanol, 50 bp DNA ladder, Trizma®, molecular biology grade DMSO, and PCR primers were supplied by Sigma-Aldrich (St. Louis, MO, USA). Low electroendosmosis (EEO) agarose was from Applichem (Darmstadt, Germany). Isopropanol, glacial acetic acid, sodium hydroxide, and EDTA were purchased from Ajax Pty Ltd (Auckland, New Zealand), and 10x NEBuffer solution and restriction enzymes (BstNI, Haell) were from Promega and New England Biolabs (Hitchin, UK).

\section{Equipment}

PCR-RFLP reactions were analyzed by electrophoresis of TAE gels containing $2.0 \%$ or $2.5 \%$ agarose. Blood samples were centrifuged in a 5415C centrifuge (Eppendorf, Hamburg, Germany). Blood samples were incubated during DNA extraction in a water bath (Memmert,
Schwabach, Germany). Meanwhile, the quantification of genomic DNA samples was done using UV-160A spectrophotometer (Shimadzu, Kyoto, Japan). The PCR-RFLP assay was performed in a PTC-100TM thermocycler (MJ Research Inc., Watertown, MA, USA). Genotyping analysis was performed using a Fluorchem FC2 gel documentation system (Alpha Innotech, Multimage ${ }^{\mathrm{TM}}$, USA).

\section{Patient recruitment}

Patients were recruited from all medical wards at the teaching hospital of the National University of Malaysia (UKMMC) and were screened for eligibility to participate in the study. The study complied with the Declaration of Helsinki [5], the Ethics Committee of UKMMC granted its approval (FPP-282-2008), and all participants gave their written, informed consent. We calculated our sample size based on a previous report [6], with a maximum of 10 independent variables involved in each analysis. Therefore, a sample size of 100 was needed for $95 \%$ power.

Subjects who met the following specifications were included: blood glucose level greater than $13.9 \mathrm{mmol} / \mathrm{L}$, severe hyperglycemia [7] or glucose level greater than $15 \mathrm{mmol} / \mathrm{L}$, acute hyperglycemia upon admission [8], over 30 years old, and only used insulin during hospitalization. Subjects who met any of the following criteria were excluded: used oral hypoglycemic agents during hospitalization, were pregnant, were unable or unwilling to give informed consent, and were critically ill or exhibited medical conditions that were likely to limit life expectancy or required extensive medical treatment. A total of $10 \mathrm{~mL}$ of venous blood was taken from T2DM patients who fulfilled the inclusion criteria to identify single nucleotide polymorphisms (SNPs) by the polymerase chain reaction-restriction fragment length polymorphism (PCR-RFLP) method $[9,10]$ in the genomic study. This study was conducted in the Molecular Biology Laboratory, Faculty of Medicine, The National University of Malaysia.

\section{Insulin resistance measurement}

Insulin resistance was assessed using an earlier described method [11].

\section{Genetic study}

\section{DNA extraction method}

The genomic DNA was extracted using the

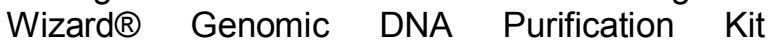
(Promega, Madison USA) according to the manufacturer's instructions. 


\section{DNA quantification}

Initially, a total of $1 \mathrm{~mL}$ of molecular biology grade water was calibrated in a spectrophotometer at wavelengths of $260 \mathrm{~nm}$ and $280 \mathrm{~nm}$. Then, $10 \mu \mathrm{L}$ of DNA solution was diluted with $990 \mu \mathrm{L}$ of molecular biology grade water and was mixed. The absorbance (OD) of the DNA solution was measured and recorded at wavelengths of $260 \mathrm{~nm}$ and $280 \mathrm{~nm}$ using a UV160A Shimadzu Spectrophotometer, and the OD260/OD280 ratio was determined. A ratio of $1.8-2.0$ indicates the range of ultraviolet absorbance due to nucleic acids. Dilution factor was calculated as the sum of DNA quantity and molecular biology grade water divided by DNA quantity. The amount of DNA (in $\mu \mathrm{g} / \mathrm{mL}$ ) was determined according to Eq 1.

DNA conc $=A \times 100 \times 50 \mu \mathrm{g} / \mathrm{mL} / 100$

where $A$ is the absorbance at $260 \mathrm{~nm}$ and 100 is the dilution factor in which the conversion values of the spectrophotometer for nucleic acids were as follows [12]:

1 unit of A260 double-stranded DNA = 50 $\mu \mathrm{g} / \mathrm{mL}$; 1 unit of A260 single-stranded DNA = $33 \mu \mathrm{g} / \mathrm{mL}$; 1 unit of $A 260$ single-stranded RNA $=40 \mu \mathrm{g} / \mathrm{mL}$

\section{Polymerase chain reaction-restriction fragment length polymorphism (PCR-RFLP) for IRS1 polymorphism r.2963G>A (p.Gly972Arg)}

To study IRS1 gene polymorphism r.2963G>A (rs 1801278), the following primers were used for PCR: 5'-CTTCTGTCAGGTGTCCATCC-3' (left primer) and 5'-TGGCGAGGTGTCCACGTAGC-3' (right primer) [9]. Before the $\mathrm{PCR}$ process started, the following mixture was prepared: $2 \mu \mathrm{L}$ containing $100 \mathrm{ng}$ of genomic DNA; $12.5 \mu \mathrm{L}$ of master mix solution (Promega) containing the enzyme Taq polymerase 50 units $/ \mathrm{mL}$ in reaction buffer solution $\mathrm{pH} 8.5,400 \mu \mathrm{M}$ each of dATP, dGTP, dCTP, and dTTP, and $3 \mathrm{mM}$ magnesium chloride solution $(\mathrm{MgCl} 2) ; 1 \mu$ of each primer; and $8.5 \mu \mathrm{L}$ of nuclease-free water to produce a reaction volume of $25 \mu \mathrm{L}$ for PCR assay. The solution was then slowly mixed in the microtubes by centrifuging and vortexing. Thereafter, the $\mathrm{PCR}$ process was initiated in a thermocycler. First, the solution was denatured for $5 \mathrm{~min}$ at 95 ${ }^{\circ} \mathrm{C}$. Then, the sample was denatured $45 \mathrm{~s}$ at the same temperature, annealed for $45 \mathrm{~s}$ at $58{ }^{\circ} \mathrm{C}$, and elongated for $45 \mathrm{~s}$ at $72{ }^{\circ} \mathrm{C}$.

Denaturation, annealing, and extension were repeated 37 times. The final extension was for 5 $\min$ at $72{ }^{\circ} \mathrm{C}$. Afterwards, the PCR products were stored at $4{ }^{\circ} \mathrm{C}$. A PCR product containing the Gly972Arg allele with the restriction enzyme BstNI site was produced. The expected size of the PCR products was 263 base pairs (bp). Genetic polymorphisms were identified by digesting PCR products with BstNI endonuclease. PCR products were digested for one hour at $60{ }^{\circ} \mathrm{C}$ in a $10 \mu \mathrm{L}$ reaction volume containing $7 \mu \mathrm{L}$ of PCR product, $0.2 \mu \mathrm{L}$ of the restriction enzyme BstNI, $1 \mu \mathrm{L}$ of $10 x$ NEBuffer solution, $0.1 \mu \mathrm{L}$ of $100 \mathrm{x}$ bovine serum albumin (BSA), and nuclease-free water to the reaction volume. BstNI cut the PCR product at position 5'CC/WGG-3' to produce fragments that were 108 $\mathrm{bp}, 81 \mathrm{bp}, 51 \mathrm{bp}$, and $23 \mathrm{bp}$ in the IRS1-972A allele and $159 \mathrm{bp}, 81 \mathrm{bp}$, and $23 \mathrm{bp}$ in the IRS1$972 \mathrm{G}$ allele. A total of $10 \mu \mathrm{L}$ of digested product was mixed with $2 \mu \mathrm{L}$ of loading dye and loaded into $2.0 \%$ agarose gel containing ethidium bromide $(20 \mathrm{mg} / \mathrm{mL})$. Gel electrophoresis conditions were $100 \mathrm{~V}$ for $50 \mathrm{~min}$. A digital image was taken after agarose gel electrophoresis using ultraviolet light transillumination.

\section{PCR-RFLP for IRS2 polymorphism r.3684G>A (p.Gly1057Asp)}

To examine the IRS2 gene polymorphism r.3684G>A (rs 1805097), we used the following primers: 5'-CCGTCGACCTGAACAACTAC-3' (left primer) and 5'-GAGGAGAAGGTCTCGGAA CT-3' (right primer) [10]. Before the PCR process started, the following mixture was prepared: $3 \mu \mathrm{L}$ containing $100 \mathrm{ng}$ of genomic DNA; $12.5 \mu \mathrm{L}$ of master mix solution (Promega) containing the Taq polymerase enzyme 50 units $/ \mathrm{mL}$ in reaction buffer solution $\mathrm{pH} 8.5,400 \mu \mathrm{M}$ each of dATP, dGTP, dCTP, and dTTP, and $3 \mathrm{mM}$ magnesium chloride solution $(\mathrm{MgCl} 2) ; 1 \mu \mathrm{L}$ of each primer; $2.5 \mu \mathrm{L}$ of dimethyl sulfoxide solution (DMSO), and $5 \mu \mathrm{L}$ of nuclease-free water to produce a reaction volume of $25 \mu \mathrm{L}$. The solution was then slowly mixed in the microtubes by centrifuging and vortexing. Thereafter, the PCR process was initiated in a thermocycler. First, the solution was denatured for $3 \mathrm{~min}$ at $95{ }^{\circ} \mathrm{C}$. Then, the sample was denatured for $30 \mathrm{~s}$ at the same temperature, annealed for $30 \mathrm{~s}$ at $47{ }^{\circ} \mathrm{C}$, and elongated for 1 $\min$ at $72{ }^{\circ} \mathrm{C}$. The PCR process was repeated 38 times. The final extension was for $5 \mathrm{~min}$ at $72{ }^{\circ} \mathrm{C}$. The PCR products were stored at $4{ }^{\circ} \mathrm{C}$. A PCR product containing allele Gly1057Asp with a restriction enzyme Haell site was produced. The expected size of the PCR product was $535 \mathrm{bp}$. Polymorphisms were identified by digesting PCR products with Haell endonuclease. PCR products were digested for one hour at $37{ }^{\circ} \mathrm{C}$ in a $10 \mu \mathrm{L}$ reaction volume containing $7 \mu \mathrm{L}$ of PCR product, $0.2 \mu \mathrm{L}$ of restriction enzyme Haell, $1 \mu \mathrm{L}$ of $10 \mathrm{x}$ NEBuffer solution, $0.1 \mu \mathrm{L}$ of $100 \mathrm{x}$ BSA, and 
nuclease-free water to the reaction volume. The Haell restriction enzyme cut the PCR product at position 5'-RGCGC/Y-3' to produce fragments that were $420 \mathrm{bp}, 62 \mathrm{bp}$, and $53 \mathrm{bp}$ for the IRS2 1057A allele and $225 \mathrm{bp}, 195 \mathrm{bp}, 62 \mathrm{bp}$, and 53 bp for the IRS2 $1057 \mathrm{G}$ allele. A total of $10 \mu \mathrm{L}$ of digested product was mixed with $2 \mu \mathrm{L}$ of loading dye and loaded into a $2.5 \%$ agarose gel containing ethidium bromide $(20 \mathrm{mg} / \mathrm{mL})$. Gel electrophoresis conditions were $100 \mathrm{~V}$ for 50 min. A digital image was taken after agarose gel electrophoresis using ultraviolet light transillumination.

\section{Fragment identification of IRS1 r.2963G>A (p.Gly972Arg) and IRS2 r.3684G>A (p.Gly1057Asp)}

For this study, PCR amplification products were digested with BstNI restriction enzyme for the IRS1 gene and Haell enzyme for the IRS2 gene. The following materials were prepared for the RFLP analysis: a solution of $10 \mu \mathrm{L}$ containing 7 $\mu \mathrm{L}$ of PCR product, $1 \mu \mathrm{L}$ of $10 \mathrm{x}$ NEBuffer solution, restriction enzymes $(0.2 \mu \mathrm{L}), 0.1 \mu \mathrm{L}$ $100 x$ BSA, and the necessary volume of nuclease-free water. Thereafter, the solution was incubated for $1 \mathrm{~h}$ at $60{ }^{\circ} \mathrm{C}$ (BstNI) and $37{ }^{\circ} \mathrm{C}$ (Haell). TAE gels containing 2.0 or $2.5 \%$ agarose were electrophoresed at $100 \mathrm{~V}$ for 50 min. The DNA bands were observed in a gel documentation system.

\section{Outcome measured}

The primary outcome measured was the SNP prevalence and its association with insulin resistance status and level of glycemic control in
T2DM patients with severe/acute phase hyperglycemia.

\section{Data analysis}

Data collected for each patient were classified by the specific allele, genotype, and haplotype. Fisher's exact test and $x^{2}$ tests were used for nominal data. Spearman's correlation was used for association of gene polymorphisms with insulin resistance. Based on Hardy-Weinberg equilibrium (HWE) test, a p-value of more than 0.05 indicated that the observed distribution of genotypes was consistent with the HWE assumption. This situation also proves that the results of the PCR-RFLP method are applicable.

\section{RESULTS}

In this study, identification of the IRS1 r.2963G>A (p.Gly972Arg) gene polymorphism was based on the SNP reference number (rs 1801278). The polymorphism occurred when nucleotide $G$ at amino acid glycine (GGG) at codon 972 was changed to nucleotide $A$ and amino acid arginine (AGG). Figure 1 shows the pattern of electrophoresis for IRS1 genotype r.2963G>A (p.Gly972Arg), which was analyzed using the PCR-RFLP assay. BstNI cut the PCR product at position 5'-CCNGG-3' to produce fragments that were $108 \mathrm{bp}, 81 \mathrm{bp}, 51 \mathrm{bp}$, and $23 \mathrm{bp}$ in the IRS1-972A allele and $159 \mathrm{bp}, 81 \mathrm{bp}$, and $23 \mathrm{bp}$ in the IRS1-972G allele. The 51 and $23 \mathrm{bp}$ fragments were only clearly visible under the ultraviolet light transillumination.

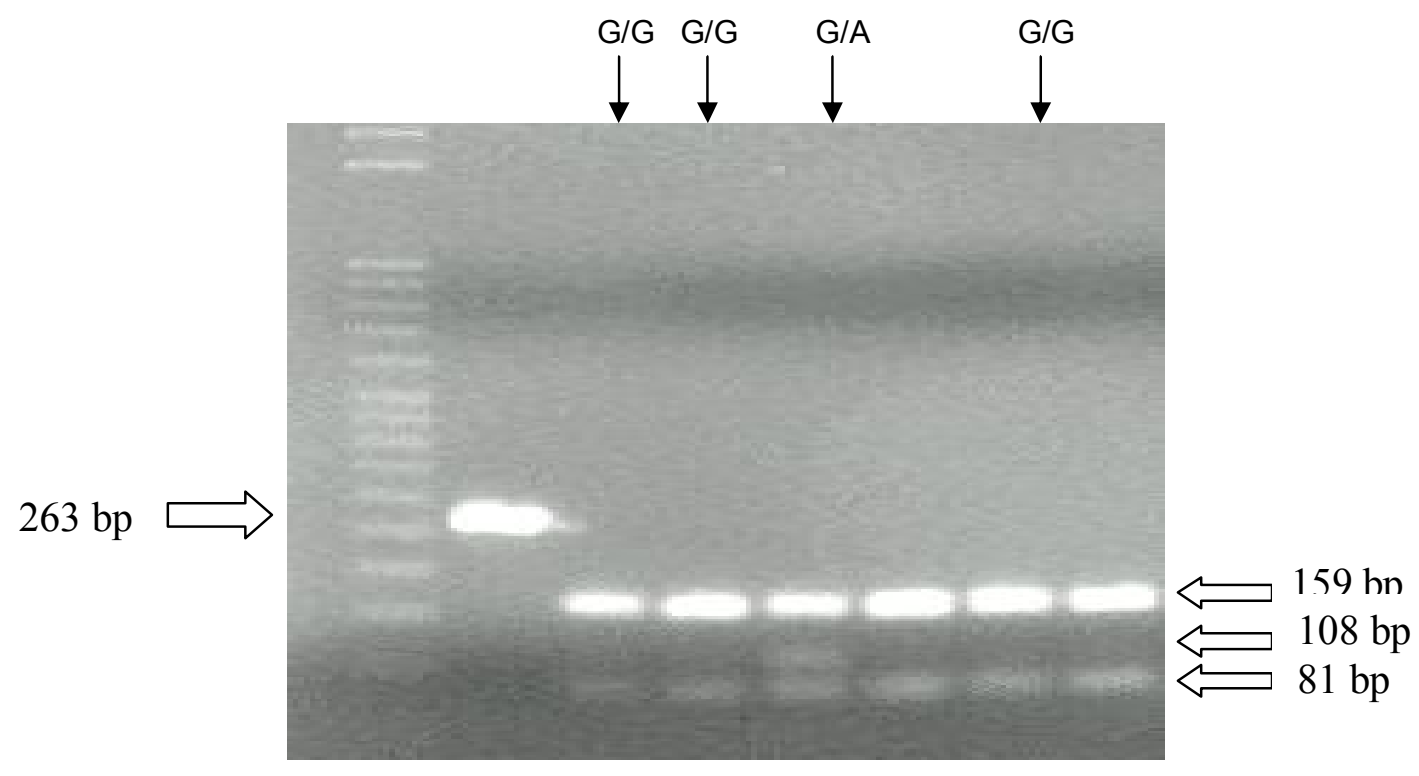

Figure 1: Identification of gene polymorphisms of IRS1 r.2963G>A (p.Gly972Arg) with the PCR-RFLP method 


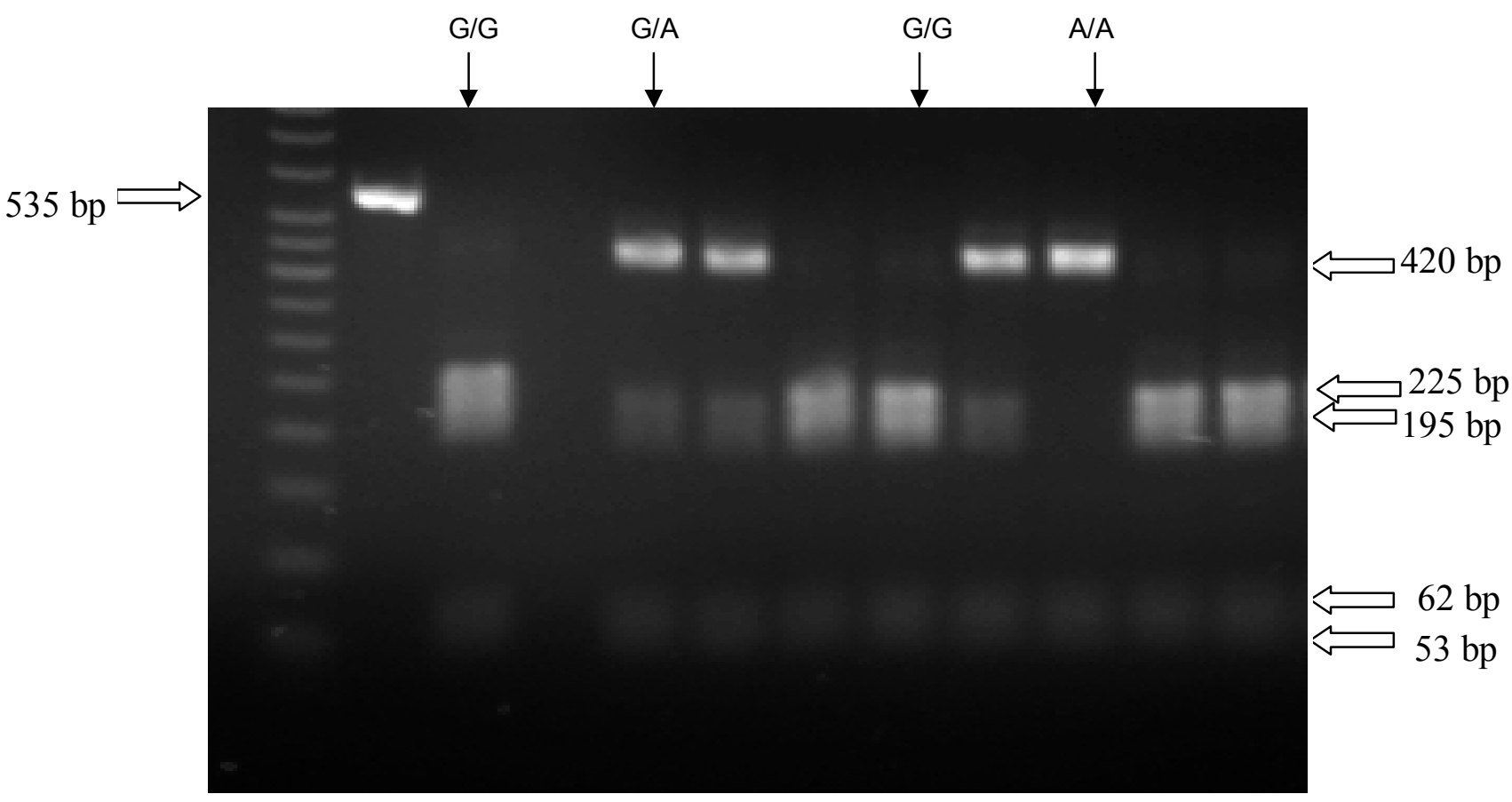

Figure 2: I dentification of gene polymorphisms of IRS2 r.3684G>A (p.Gly1057Asp) with the PCR-RFLP method

To identify IRS2 r.3684G>A (p.Gly1057Asp) gene polymorphisms in IRS2, the SNP reference number used was rs1805097. In this polymorphism, nucleotide $G$ at amino acid glycine (GGG) was changed to nucleotide $A$ and amino acid aspartate (GAC) at codon position 1057 as shown in Figure 2. The Haell restriction enzyme cut the PCR product at position 5'RGCGC/Y -3 ' to produce fragments that were 420 bp, $62 \mathrm{bp}$, and $53 \mathrm{bp}$ for the IRS2 1057A allele and $225 \mathrm{bp}, 195 \mathrm{bp}, 62 \mathrm{bp}$, and $53 \mathrm{bp}$ for the IRS2 1057G allele.

The results obtained for IRS1 genes [p $(\mathrm{HWE})=$ 0.6481] and IRS2 [p (HWE) $=0.7627$ ] genes were consistent with the HWE test.

Table 1 provides the distribution of allele and genotype of IRS1 and IRS2 gene polymorphisms in the study sample.
Prevalence of R.2963 IRS1 G>A (p.Gly972Arg) and IRS2 r.3684G>A (p.Gly1057Asp) genotype polymorphisms among T2DM patients with severe/acute hyperglycemia

The prevalence of the IRS1 polymorphism r.2963G>A (p.Gly972Arg) in the study population was $7.1 \%$. Table 2 shows the significant differences $\left(X^{2}\right.$ test $\left.=5.19, p=0.023\right)$ between the variations in the IRS1 gene polymorphism based on the insulin resistance status. In this study, the prevalence of the IRS2 r.3684G $>A$ (p.Gly1057Asp) polymorphism was $65.3 \%$, which included a combination of homozygous $(17.9 \%)$ and heterozygous polymorphisms (47.4 $\%)$. No significant difference $\left(X^{2}\right.$ test $=0.69, p=$ 0.406 ) was detected between the IRS2 gene polymorphisms and the insulin resistance status (Table 2).

Table 1: Comparison of the allele and genotype distributions for IRS1 Gly972Arg and IRS2 Gly1057Asp gene polymorphisms by race/ethnicity $(n=156)$

\begin{tabular}{lccccc}
\hline \multirow{2}{*}{ Study } & \multicolumn{5}{c}{ Frequency } \\
\cline { 2 - 6 } & \multicolumn{3}{c}{ Allele } & & Genotype \\
\cline { 2 - 6 } & $\mathrm{A}$ & $\mathrm{G}$ & $\mathrm{A} / \mathrm{A}$ & $\mathrm{G} / \mathrm{A}$ & $\mathrm{G} / \mathrm{G}$ \\
\cline { 2 - 6 } IRS1 Gly972Arg & 0.035 & 0.965 & 0 & 0.071 & 0.929 \\
IRS2 Gly1057Asp & 0.417 & 0.583 & 0.179 & 0.475 & 0.346 \\
\hline
\end{tabular}


Table 2: Comparison of IRS1 gene variants by insulin resistance status

\begin{tabular}{lccc}
\hline $\begin{array}{l}\text { Variant of } \\
\text { polymorphism } \\
\text { IRS1 Gly972Arg }\end{array}$ & $\begin{array}{c}\text { Insulin- } \\
\text { sensitive }\end{array}$ & $\begin{array}{c}\text { Insulin- } \\
\text { resistant }\end{array}$ & Total \\
\hline GA & 6 & 5 & 11 \\
GG & 34 & 111 & 145 \\
Total & 40 & 116 & $\mathbf{1 5 6}$ \\
Variant of IRS2 & & & \\
Gly1057Asp & & & \\
GG & 16 & 38 & 54 \\
AA/GA & 24 & 78 & 102 \\
Total & $\mathbf{4 0}$ & $\mathbf{1 1 6}$ & $\mathbf{1 5 6}$ \\
\hline
\end{tabular}

\section{DISCUSSION}

This study showed that IRS1 gene polymorphisms increased insulin resistance in T2DM patients with severe or acute hyperglycemia. Only the IRS1 Gly972Arg gene polymorphism influenced insulin resistance in T2DM patients who experienced severe/acute hyperglycemia. This result is similar to the results in a study by Villuendas et al [13]. 2005, in which only the Arg972 IRS1 gene polymorphism ( $\mathrm{F}=$ $7,529, p=0.007$ ) influenced insulin resistance and IRS2 gene polymorphisms did not have an effect. In addition, studies conducted by El Mkadem [14] and Villuendas et al [13] also found that the r.2963G>A (p.Gly972Arg) IRS1 gene polymorphism occurs in patients with insulin resistance, and these polymorphisms also affect insulin resistance.

Other studies at the molecular level revealed that the r.2963 IRS1 polymorphism G> A (p.Gly972Arg) acted as a competitive inhibitor to the IR and IGF-1R autophosphorylation. The IRS1 gene polymorphism not only is a reducing phosphorylation substrate but also allows the IRS1 gene to act as an inhibitor to IR kinase, causing global insulin resistance [14]. Overall, r.2963 IRS1 polymorphism G>A (p.Gly972Arg) may contribute to insulin resistance by weakening the ability of insulin to activate the signaling pathway of IRS1/PI3kinase/Akt/glycogen synthase kinase-3 in insulinsensitive tissues [4].

In this study, the prevalence of the r.2963G>A (p.Gly972Arg) IRS1 polymorphism was lower than that earlier reported $[10,13]$. This may be because the other studies assessed the association with the T2DM disease in general, while this study is more specific to the group of patients with severe or acute hyperglycemia. Although the comparison of the distribution of alleles and genotypes for Gly972Arg IRS1 gene polymorphisms in other racial/ethnic groups found that there were differences between the population in the current study and the Caucasian population in Italy, this comparison is made in view of the characteristics of study subjects that were also different. None of the previous studies investigated the association between gene polymorphisms and T2DM acute phase or severe hyperglycemia.

Most previous studies related to IRS2 gene polymorphisms focused on diabetes and obesity in general. The results of this study were consistent with those of studies involving the Pima Indian population. In the Pima Indian community, the frequency of alleles in the polymorphism Gly1057Asp Asp1057 IRS2 gene was the highest compared with that in other populations $[10,14]$. This may be because of the high prevalence of T2DM in the population. Another study on the Caucasians in Italy found that the diabetes risk was low in lean Asp1057 allele carriers compared to obese subjects [15]. Discrepancies in the results explain the differences in genetic background and are supported by differences in allele-allele frequency. Molecular mechanisms related to this polymorphism are still unknown. Aspartic acid is a charged amino acid. The exchange of amino acids is close to the assumed two phosphorylation sites of tyrosine (1042 and 1072) in the protein. Thus, changes in downstream signaling through the IRS2 gene may be involved. However, there is a possibility that this polymorphism is not functioning but is in linkage disequilibrium with other functional polymorphisms that have not been identified.

In another study by Fritsche et al [10], polymorphisms of the gene IRS2 Gly1057Asp were not related to beta cell dysfunction. This conclusion is based on the maximum response in normal cells and insulin secretion found in the study. Similar to the IRS1 polymorphism, no studies have investigated IRS2 polymorphisms in T2DM patients who suffer severe or acute hyperglycemia.

\section{CONCLUSION}

IRS1 genetic factor alone may be a significant genetic determinant for insulin resistance in T2DM patients in severe/acute phase hyperglycemia. 


\section{Limitation of the study}

This study focused on a specific study population; hence, it might not be possible to extrapolate these results to other races or countries.

\section{ACKNOWLEDGEMENT}

The authors would like to thank the National University of Malaysia; University of Malaya, Malaysia, and the Ministry of Higher Education Malaysia for financial and technical support.

\section{REFERENCES}

1. Huri HZ, Min YS, Pendek R: Episodes of hypoglycemia and hyperglycemia during the use of sliding scale insulin in hospitalized diabetes patients. Asian Biomed 2007; 1: 307-311.

2. American Diabetes Association: Standard of medical care in diabetes. Diabetes Care 2012; 35: S11-S63.

3. Burgering BM, Coffer PJ: Protein kinase $B$ (c-Akt) in phosphatidylinositol-3-OH kinase signal transduction. Nature 1985; 376: 599-602.

4. Aileen JM, Edward PF, Ronald K: Human insulin receptor substrate-1 (IRS-1) polymorphism G972R causes IRS-1 to associate with the insulin receptor and inhibit receptor autophosphorylation. J Biol Chem 2005; 280: 6441-6446.

5. World Medical Association: Declaration of Helsinki. Ethical principles for medical research involving human subjects. 59th WMA General Assembly, Seoul; 2008.

6. Green S. How many subjects does it take to do a regression analysis? Multivariate Behav Res. 1991; 26: 499-510.

7. Inzucchi SE: Management of hyperglycemia in the hospital setting. N Engl J Med 2006; 355: 1903-1911.

8. Marfella R, Verrazzo G, Acampora R, La Marca C, Giunta $R$, Lucarelli C, Paolisso G, Ceriello A, Giugliano D: Glutathione reverses systemic hemodynamic changes induced by acute hyperglycemia in healthy subjects. Am J Physiol 1995; 268: E1167-E11173.

9. Federici $M$, Petrone $A$, Porzio $O$, Bizzarri $C$, Lauro $D$, D'Alfonso DR, Patera I, Cappa M, Nisticò L, Baroni M et al: The Gly972Arg IRS-1 variant is associated with type 1 diabetes in Continental Italy. Diabetes 2003; 52: 887-890.

10. Fritsche A, Madaus A, Renn W, Tschritter O, Teigeler A, Weisser M, Maerker E, Machicao F, Häring $H$, Stumvoll M: The prevalent Gly1057Asp polymorphism in the insulin receptor substrate-2 gene is not associated with impaired insulin secretion. J Clin Endocrinol Metab 2001; 86: 4822-4825.

11. Zaman Huri H, Makmor-Bakry M, Hashim, R., Mustafa, N., \& Wan Ngah, W. Z. Optimisation of glycaemic control during episodes of severe/acute hyperglycemia in patients with type 2 diabetes mellitus. International Journal of Clinical Pharmacy 2012; 34(6): 863-870.

12. Hoisington $D R, \quad K h a i r a l l a ~ M, ~ G o n z a l e z-d e-L e o n:$ Laboratory protocols: CIMM-YT Applied Biotechnology Center. Second Edition, D. Mexico, D.F.: CIMMYT; 1994.

13. Villuendas G, Botella-Carretero JI, Roldan B, Sancho J, Escobar-Morreale HF, San Millan JS: Polymorphisms in the insulin receptor substrate-1 (IRS1) gene and the insulin receptor substrate-2 (IRS2) gene influence glucose homeostasis and body mass index in women with polycystic ovary syndrome and nonhyperandrogenic controls. Hum Reprod 2005; 20 : 3184-3191.

14. El Mkadem SA, Lautier C, Macari F, Molinari N, Lefebvre $P$, Renard E, Gris JC, Cros G, Daures JP, Bringer J, White MF, Grigorescu F: Role of allelic variants Gly972Arg of IRS-1 and Gly1057Asp of IRS-2 in moderate-to severe insulin resistance of women with polycystic ovary syndrome. Diabetes 2001; 50: 21642168.

15. Mammarella S, Romano F, Di Valerio A, Creati $B$, Esposito DL, Palmirotta R, Capani F, Vitullo $P$, Volpe $G$, Battista $P$, Della Loggia F, Mariani-Costantini R, Cama A: Interaction between the G1057D variant of IRS-2 and overweight in the pathogenesis of type 2 diabetes. Hum Mol Genet 2000; 9: 2517-2521. 